\begin{tabular}{|c|c|c|}
\hline & Journal Homepage: - www.journalijar.com & $\begin{array}{l}\text { INTERNATIONAL JOURNAL OF } \\
\text { ADVANCED RESEARCH (IJAR) }\end{array}$ \\
\hline ISSN NO. 2320-5407 & $\begin{array}{l}\text { Article DOI: } 10.21474 / \text { IJAR01/3030 } \\
\text { DOI URL: http://dx.doi.org/10.21474/IJAR01/3030 }\end{array}$ & \\
\hline
\end{tabular}

RESEARCH ARTICLE

\title{
AWARENESS ON AGICULTURAL BUDGETING - AN OVERVIEW.
}

P. Sindhuja ${ }^{1}$ and Dr. M. Asokhan ${ }^{2}$.

1. Ph.D Research Scholar, Department of Agricultural Extension and Rural Sociology, Tamil Nadu Agricultural University, Coimbatore-641 003.

2. Professor (Agricultural extension), Department of Agricultural Extension and Rural Sociology, Tamil Nadu Agricultural University, Coimbatore-641 003.

\section{Manuscript Info}

\section{Manuscript History}

Received: 30 November 2016

Final Accepted: 28 December 2016

Published: January 2017

\section{Key words:-}

Budget, Awareness, Agricultural budgeting

\section{Abstract}

Budget is the financial statement for a period of time helps in aiding the plan of actions which may focus for the development. This study entitled "AWARENESS ON AGICULTURAL BUDGETING - AN OVERVIEW" helps to understand about the budget, agricultural budgeting, History of evaluation of budgeting, its role, purpose and importance. Study also focus on statistics of national and international budgeting and contributions of agricultural budgeting to overall budgeting. Agricultural budgeting from the union budget over a five year period was test analyzed and awareness was test among 45 samples includes Farmer, extension officials and students. Suggestion was also sorted and provided to helps in future policies implications and references for future studies.

Copy Right, IJAR, 2016,. All rights reserved.

\section{Introduction:-}

The word budget is derived from bowgette, which means 'a leather bag' in French. The budget is announced to disclose the government's future expenditures intended to strengthen the nation's economy and consolidate economic stability through tax proposals.

A Buget is a quantitative expression of a plan for a defined period of time. It may include planned sales volumes and revenues, resource quantities, costs and expenses, assets, liabilities and cash flows. It expresses strategic plans of business units, organizations, activities or events in measurable terms. A budget is the sum of money allocated for a particular purpose and the summary of intended expenditures along with proposals for how to meet them. (www.investopedia.com/university/budgeting/)

Budgeting makes it easier for people with incomes and expenses of all sizes to make conscious decisions about how they'd prefer to allocate their money (www.practicalmoneyskills.com/personalfinance/savingspending/budgeting/). A budget can help you keep track of your spending, prepare for unexpected expenses and find ways to save money (www.practicalmoneyskills.com/personalfinance/savingspending/budgeting/). A budget can help you keep track of your spending, prepare for unexpected expenses and find ways to save money (www.getsmarteraboutmoney.ca > Home > Managing your money)

Corresponding Author:- P. Sindhuja.

Address:- Ph.D Research Scholar, Department of Agricultural Extension and Rural Sociology, Tamil

Nadu Agricultural University, Coimbatore-641 003. 
The budget is announced to disclose agenda regarding government's future expenditure to strengthen nation's economy and consolidate economic stability through tax proposals. In India budget is prepared by the Budget Division Department of Economic Affairs of the Ministry of Finance annually. This includes supplementary excess grants and when a proclamation by the President as to failure of Constitutional machinery is in operation in relation to a State or a Union Territory, preparation of the Budget of such State. The railway budget is presented separately by the Ministry of Railways. Thus budget is presented in two categories: The General Budget and The Railway Budget. In this paper the trend of agricultural contribution in union budget over the past five years and awareness on agricultural budgeting is analyzed.

\section{Indian Budget: A Brief History:-}

In history of Indian budget, budget was first introduced in India on 7 April, 1860 by the East-India Company to the British Crown. Pre-independence finance minister, James Wilson presented the budget in 1860 . India has had 25 finance ministers since Independce. One week prior to the disclosure, publishers of the budget under the finance ministry, are kept isolated from the press and other sources.Earlier budget papers were printed in Rashtrapati Bhavan. The printing venue was shifted to Minto Road in New Delhi. Since 1980, budget papers are printed in the North Block. Shanmukham Chetty, first Finance Minister of India presented the budget in November 1947 without any tax proposals. However, he presented the analysis of the economic scenario of Independent India just 95 days before the budget presentation in 1948.Liaquat Ali Khan was the finance minister of the All India Muslim League from October 1946 to Independence in 1947. Till now there are nineteen finance ministers the list and frequencies are given in the following table.

Table 1:- Frequencies of finance minister from Independence.

\begin{tabular}{|c|c|c|}
\hline S.No. & Finance ministers & Frequency \\
\hline 1 & Liaquat Ali Khan & 1 \\
\hline 2 & R. K. Shanmukham Chetty & 1 \\
\hline 3 & John Mathai & 1 \\
\hline 4 & C. D. Deshmukh & 2 \\
\hline 5 & T. T. Krishnamachari & 1 \\
\hline 6 & Jawaharlal Nehru & 1 \\
\hline 7 & Sachindra Chaudhuri & 1 \\
\hline 8 & Morarji Desai & 1 \\
\hline 9 & Indira Gandhi & 1 \\
\hline 10 & Yashwantrao Chavan & 1 \\
\hline 11 & Chidambaram Subramaniam & 2 \\
\hline 12 & Madhu Dandavate & 3 \\
\hline 13 & Yashwant Sinha & 2 \\
\hline 14 & Manmohan Singh & 4 \\
\hline 15 & Jaswant Singh & 1 \\
\hline 16 & P. Chidambaram & \\
\hline 17 & I.K. Gujral & \\
\hline 18 & Pranab Mukherjee & 1 \\
\hline 19 & Arun Jaitley & \\
\hline
\end{tabular}

\section{Objective:-}

- To understand about the budgeting.

- To analyse the trend of agricultural budgeting in union budgeting .

- To test analyse the awareness of agricultural budgeting among different stake holders.

- To analyse the constraints and provide suggestion for future studies and policy implication

\section{Budget:-}

A budget is the sum of money allocated for a particular purpose and the summary of intended expenditures along with proposals for how to meet them (https://en.wikipedia.org/wiki/Budget) 
Budgeting is the process of creating a plan to spend your money. This spending plan is called a budget. Creating this spending plan allows you to determine in advance (http://www.mymoneycoach.ca/budgeting/what-is-a-budgetplanning-forecasting)

\section{Purpose:-}

Budget helps to aid the planning of actual operations by forcing managers to consider how the conditions might change and what steps should be taken now and by encouraging managers to consider problems before they arise. It also helps co-ordinate the activities of the organization by compelling managers to examine relationships between their own operation and those of other departments. Other essentials of budget include:

- To control resources

- To communicate plans to various responsibility center managers.

- To motivate managers to strive to achieve budget goals.

- To evaluate the performance of managers

- To provide visibility into the company's performance

- For accountability

\section{Types:-}

Sales budget:- an estimate of future sales, often broken down into both units and currency. It is used to create company sales goals.

Production budget:- An estimate of the number of units that must be manufactured to meet the sales goals. The production budget also estimates the various costs involved with manufacturing those units, including labor and material. Created by product oriented companies.

Capital budget:- Used to determine whether an organization's long-term investments such as new machinery, replacement machinery, new plants, new products, and research development projects are worth pursuing.

Cash flow/cash budget:- A prediction of future cash receipts and expenditures for a particular time period. It usually covers a period in the short-term future. The cash flow budget helps the business determine when income will be sufficient to cover expenses and when the company will need to seek outside financing.

Marketing budget:- an estimate of the funds needed for promotion, advertising, and public relations in order to market the product or service.

Project budget:- a prediction of the costs associated with a particular company project. These costs include labour, materials, and other related expenses. The project budget is often broken down into specific tasks, with task budgets assigned to each. A cost estimate is used to establish a project budget.

Revenue budget:- Consists of revenue receipts of government and the expenditure met from these revenues. Tax revenues are made up of taxes and other duties that the government levies.

Expenditure budget:- includes spending data items.

Corporate budget- short term financial plan but it not an finished budget

Event management budget:- to manage the event

An analysis of agricultural budgeting-trend and awareness analysis:-

\section{Methodology:-}

Agricultural budgeting from the union budget over a five year period was test analysed among 45 samples includes Farmer, extension officials and student. To detect the awareness, questioners were developed and asked to fill the respondents and result was calculated using Trend and simple percentage analysis. The awareness on Farmers, student and extension officials was studied, suggestion was also sorted and provided to helps in future policies implications and references for future studies. 


\section{Trend analysis - contribution of agriculture in union budget:-}

Trend analysis tries to predict a trend. Trend is the general direction taking during a specified period of time, trend can be both rise or fall. Trend analysis is the process of trying to look at current trends in order to predict future ones. Here trend is analyzed in union budget over past five year and their contribution to agricultural sector is analyzed.

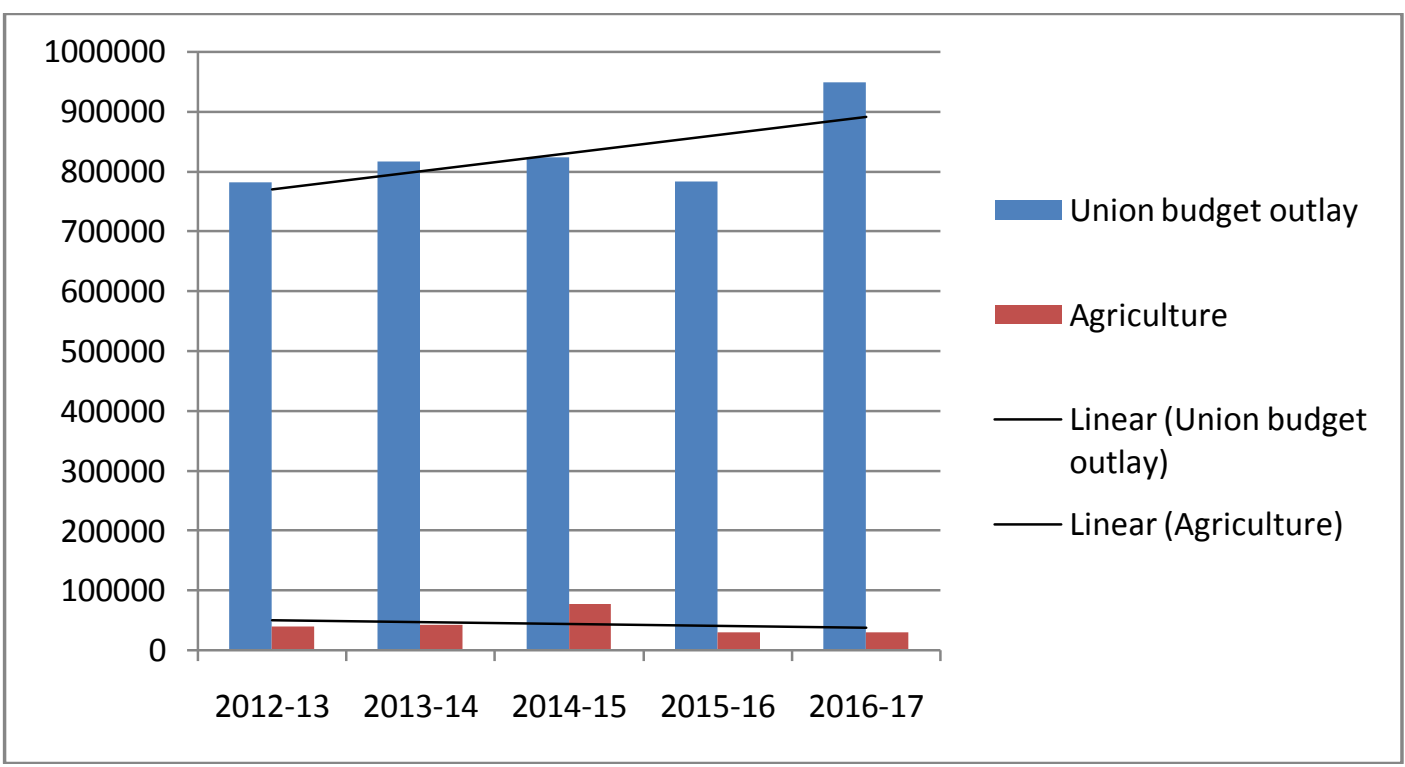

Table 2:- Contribution of agriculture in union budget for past five years

\begin{tabular}{|l|l|l|l|}
\hline Year & Union budget outlay & Agriculture & \% Contribution \\
\hline $2012-13$ & 781507.3 & $\mathbf{4 0 2 4 3 . 8 8}$ & 5.14 \\
\hline $2013-14$ & 816377.4 & $\mathbf{4 3 3 7 3 . 0 2}$ & 5.31 \\
\hline $2014-15$ & 822940.9 & $\mathbf{7 7 5 9 2 . 7 7}$ & 9.42 \\
\hline $2015-16$ & 783165.7 & $\mathbf{3 0 7 4 7 . 5}$ & 3.92 \\
\hline $2016-17$ & 948148.8 & $\mathbf{3 0 1 2 4 . 0 6}$ & 3.17 \\
\hline
\end{tabular}

The above trend analysis in the union budget shows continuous improvement except in $2015-2016$ shows slight decrease and improvement. For contribution of agriculture in union budget shows the increase in trend over a three years and decrease thereafter for the remaining two years.

\section{Finding and Discussion:-}

\section{Gender}

Gender is the range of characteristics pertaining to, and differentiating between, masculinity and femininity. The distribution of respondents according to different gender is presented in Table 3.

Table 3:- Distribution of Respondents according to gender $(\mathrm{n}=45)$

\begin{tabular}{|l|l|l|l|}
\hline S. No. & Category & Number & Per cent \\
\hline 1 & Male & 26 & 57.8 \\
\hline 2 & Female & 19 & 42.2 \\
\hline & Total & $\mathbf{4 5}$ & $\mathbf{1 0 0 . 0 0}$ \\
\hline
\end{tabular}

Table 3 revealed that 57.8 per cent of the respondents were found to be male and the remaining 42.2 per cent were found male. The higher in female participation is due to higher contribution of female members in PG education.

\section{Participation:-}

Participation in formal and non-formal community organizations might have paved way to have interaction with varied people which would help an individual to improve his knowledge and behavior. The distribution of respondents according to total participation is presented in Table 4. 
Table 4:- Distribution of Respondents according to total participation $(n=45)$

\begin{tabular}{|l|l|l|l|}
\hline S. No. & Category & Number & Per cent \\
\hline 1 & Farmers & 15 & 33.3 \\
\hline 2 & Extension officials & 15 & 33.3 \\
\hline 3 & Students & 15 & 33.3 \\
\hline & Total & $\mathbf{4 5}$ & $\mathbf{1 0 0 . 0 0}$ \\
\hline
\end{tabular}

Table 4 revealed that equal sampling of respondents selected for the study.

\section{Awareness:-}

Awareness is the degree to test the consciousness on particular topic. The distribution of respondents according to awareness is presented in Table 5.

Table 5a:- Distribution of Respondents according to awareness on budgeting $(n=45)$

\begin{tabular}{|l|l|l|l|}
\hline S. No. & Category & Number & Per cent \\
\hline 1 & Yes & 43 & 95.6 \\
\hline 2 & No & 2 & 4.4 \\
\hline & Total & $\mathbf{4 5}$ & $\mathbf{1 0 0 . 0 0}$ \\
\hline
\end{tabular}

Table 5b:- Distribution of Respondents according to awareness on agricultural budgeting $(\mathrm{n}=45)$

\begin{tabular}{|l|l|l|l|}
\hline S. No. & Category & Number & Per cent \\
\hline 1 & Yes & 44 & 97.8 \\
\hline 2 & No & 1 & 2.2 \\
\hline & Total & $\mathbf{4 5}$ & $\mathbf{1 0 0 . 0 0}$ \\
\hline
\end{tabular}

Table 5a revealed that 95.6 per cent of the respondents were found to be aware on budgeting and the remaining 4.4 per cent were found to be non aware on budgeting. Table $5 \mathrm{~b}$ revealed that 97.8 per cent of the respondents were found to be aware on agricultural budgeting and the remaining 2.2 per cent were found to be non aware on agricultural budgeting. The higher awareness is seen mainly because of budget reach.

\section{Usefulness of budgeting:-}

The degree in which the test measures the intent to measure is based on usefulness. The distribution of respondents according to responses based on usefulness of budgeting in the aspect of favouring farmers is presented in Table 6.

Table 6:- Distribution of Respondents according to responding usefulness $(n=45)$

\begin{tabular}{|l|l|l|l|}
\hline S. No. & Category & Number & Per cent \\
\hline 1 & Yes & 30 & 66.7 \\
\hline 2 & No & 15 & 33.3 \\
\hline & Total & $\mathbf{4 5}$ & $\mathbf{1 0 0 . 0}$ \\
\hline
\end{tabular}

Table 6a. revealed that 66.7 per cent of the respondents told that budgeting was in the aspect of favoring the farmers and the remaining 33.3 per cent were told it not at all favours. As the result majority of the respondents told that the budget is usefull and favours thefarmers.

Table 6b:- Distribution of respondents according to usefulness $(n=45)$

\begin{tabular}{|c|l|c|c|}
\hline S. No. & Category & Number & Per cent \\
\hline 1 & Unfavour & 12 & 26.7 \\
\hline 2 & Up to 25\% & 5 & 11.1 \\
\hline 3 & $25 \%-50 \%$ & 10 & 22.2 \\
\hline 4 & $50 \%-75 \%$ & 9 & 20.0 \\
\hline 5 & $75 \%-100 \%$ & 9 & 20.0 \\
\hline & Total & 45 & 100.0 \\
\hline
\end{tabular}

Table $6 \mathrm{~b}$ revealed that 26.7 per cent of the respondents were told budget unfavour the farmers and 22.2 per cent told that budget favours farmers $25 \%-50 \%$, the higher responses reveals unfavourness because of some constraints like lack of technology reach to the unreached farmers 
Table 7:- Sugesstions $(\mathrm{n}=45)$

\begin{tabular}{|c|c|c|c|}
\hline Sugesstions & Frequency & Percent & Rank \\
\hline No idea & 2 & 4.4 & - \\
\hline $\begin{array}{l}\text { Extensionist should be a good and effective mediator in transferring the } \\
\text { technology }\end{array}$ & 3 & 6.7 & VI \\
\hline $\begin{array}{l}\text { High awareness should be given through practicing improved transfer of } \\
\text { technology tools }\end{array}$ & 6 & 13.3 & III \\
\hline Agri in budgeting should be bottom up approach & 9 & 20.0 & I \\
\hline $\begin{array}{l}\text { Should treat all farmers equal while framing budget without segregation of } \\
\text { small, medium and large farmers }\end{array}$ & 3 & 6.7 & VI \\
\hline Improving number of field assistant in agriculture for technology transfer & 1 & 2.2 & $\mathrm{X}$ \\
\hline $\begin{array}{l}\text { Awarness about budgeting should given through popular channel other } \\
\text { than Pothigai etc., }\end{array}$ & 7 & 15.6 & II \\
\hline $\begin{array}{l}\text { Export, import and marketing aspects in agri in budgeting should be } \\
\text { improved }\end{array}$ & 1 & 2.2 & $\mathrm{X}$ \\
\hline Separate agriculture budget in budget is needed & 4 & 8.9 & IV \\
\hline $\begin{array}{l}\text { Allocating budget in the form of subsidies should be impressive schemes } \\
\text { other than waiving loans }\end{array}$ & 3 & 6.7 & VI \\
\hline $\begin{array}{l}\text { Correct time, correct delivery of input in the form of subsidy should be } \\
\text { monitor properly to rectify the delay reach to the farmers }\end{array}$ & 4 & 8.9 & IV \\
\hline $\begin{array}{l}\text { Entire budget monitoring approaches should be digitalized to reach the } \\
\text { effectiveness in reach }\end{array}$ & 2 & 4.4 & IX \\
\hline
\end{tabular}

* Multiple responses

Table 7 reveals the sugesstion given by the respondents to increase awareness and to reach the unreach farmers

\section{Conclusion:-}

Awareness on agricultural budgeting reveals the awareness level on budgeting and agricultural budgeting aspects at markable level, the trend analyzed for past five years shows increase trend line with slight fluctuations, from the overall study it is clear that the awareness about budgeting and agricultural budgeting is high among the respondents.

\section{References:-}

1. Pleasant. (2013). What is Budgeting? What is a Budget? Retrieved October 06, 2016, from http://www.mymoneycoach.ca/budgeting/what-is-a-budget-planning-forecasting

2. Fontinelle, A. (2008). Budgeting Basics. Retrieved September 17, 2016, from http://www.investopedia.com/university/budgeting/

3. Budgeting. $\quad$ (2013). Retrieved $\quad$ September $\quad 26, \quad$ 2016, from http://www.practicalmoneyskills.com/personalfinance/savingspending/budget/

4. Budget. Retrieved October, 2016, from www.tnbudget.tn.gov.in/

5. Osmond Vitez, \& Studio. Why Is it Important for a Business to Budget? Retrieved October, 2016, from http://smallbusiness.chron.com/important-business-budget-385.html

6. Union budget (2016). Retrieved from http://www.unionbudget.nic.in/

7. Budget. (n.d.)., from https://en.wikipedia.org/wiki/Budget

8. United States federal budget. (2007.). Retrieved November 07, 2016, from https://en.wikipedia.org/wiki/United_States_federal_budget

9. World budget. (World Wide Words: Budget. Retrieved November, 2016, from http://www.worldwidewords.org/topicalwords/tw-bud1.htm 